\title{
Managing the Innovative Deployment of Information and Communication Technologies (ICTs) for Global Service Organisations
}

\author{
Martin R. Fellenz, School of Business, Trinity College Dublin \\ Email: Martin.Fellenz@tcd.ie \\ and \\ Mairead Brady, School of Business, Trinity College Dublin \\ Email: Mairead.Brady@tcd.ie
}

The question on how to organise and manage global services is important and timely given the growth in services which are fast overtaking products as the basis for the predominant economic model for companies and countries. As services are increasingly traded internationally, many service firms are becoming more global by moving from national to international, multinational, global, and ultimately transnational firms (Bartlett \& Ghoshal, 1987). The ever rising proportion of internationally traded services as a proportion of GNP indicates the management of this development as an important area for academic study. Such investigations are also important for those researchers and practitioners primarily interested in products rather than services, as relevant services such as supply chain management, telecommunications, call centres staffing, or payroll and other administrative services that are central to the successful management and operation even of product oriented firms are increasingly supplied on an international basis by global service providers.

This paper is focused on how information and telecommunication technologies (ICTs) are - and can be - deployed for global service provision. In our arguments we are less concerned with the ICT deployment for managing the global service firm. These important concerns have repeatedly been addressed in the literature (e.g., Boudreau, Loch, Robey, \& Straub, 1998; Shore, 2006). Rather, we investigate the challenge of how ICT can most usefully be deployed in service delivery and customer interface management of 
internationally active service organisations. We consider particularly the consequences of the rationale underlying the increasing globalisation of services with the logic of service delivery. As part of this we reflect on the managerial and organisational implications of ICT deployment in global service firms.

A basic premise or our argument is that the reasoning which drives companies to move to global services development and provision is often based on a synergy and efficiency oriented logic. This efficiency logic is the basis on which most global service organisations are trying to build sustainable business models and to achieve a competitive advantage. " $A$ firm operating globally must manage the flow of people, information, services and money across national borders. It must nurture and cultivate distinct competence that will allow it to offer better or more efficient services than the domestic firm, as well as the executive reward system and the systems of coordination and control that will nurture its strategy" (Aharoni, 1996). Within this efficiency logic, ICT is often used to enable - and almost as often implicitly or explicitly simply equated with - increased efficiency. As a result, ICT is generally deployed automatically and without adequate reflection. This unreflected use can violate the firm's service proposition because such deployment may not be aligned with the underlying value proposition for customers and the resulting sustainable service business model that needs to also heed the relational aspects of the service logic.

A central finding from the limited studies on successful service organisations indicates that they tend to employ a particular service logic that combines a fundamental focus on relational aspects while also reflecting transactional aspects. (Gummesson, 1998, 2002; Grönroos, 2004). In the context of service provision, the way in which ICT is deployed in both service delivery and in the management of the consumer interface often violates part of this underlying relational logic. In particular the question of the overall impact of increasing deployment of ICT from both organisational and customer perspectives has not been sufficiently explored. In the case of global services does - or can -- ICT replace the human dimension of service provision and consumer interface management? This question is particularly important in the 
context of global services because the logic of globalisation is so intertwined with the notion of efficiency as the key competitive issue for global companies (Bartlett \& Ghoshal, 1987). This notion is closely aligned with the transactional aspects of service delivery which at its heart is very product orientated. Thus, moves towards globalised services may inherently conflict with the relational aspects of the service logic itself unless a more holistic perspective on ICT deployment is considered and heeded. To address this issue we consider the question how ICT can be a core part of a global services operation but also be reflective of the differential customer needs and the subsequently customised delivery and interface management approaches in different markets.

The extant literature in this area suggests that ICT needs to be subservient to the creation of value for the customer (Meuter et al, 2002; Bitner et al., 2000). Decisions on how to use ICT are too often driven by what is technologically possible rather then what adds value to the service partners. In this paper we argue that it is important to understand the role of ICT within the global service provision and to focus on the relationship and the technology in a holistic fashion that reflects several key perspectives. The current practice of trying to realize the full potential of a particular technology may in the longer term be detrimental to maintaining, growing, and exploiting sustainable service relationships with customers.

This paper reviews global service provision from a relational perspective. It then links to the automational nature of much of ICT within organisations. This is further related to a review of how ICT moves aspect of the relational dimensions of services to a transactional or automational level. We suggest that technologist need to understand relational customer requirements, and that internal customer advocates such as marketers need to be cognisant of technological opportunities and limitations, and also need to be able to engage in meaningful dialogue with technologists in order to maximise the economic and relational value to be gained from ICT. There are thus three orientations that need to be considered jointly: the economic, the technological, and the marketing perspective. These three different views all require attention, but none can deliver the full value required in competitive service markets. Thus, the three sets of objectives require arbitration or ideally integration to align 
technological potential with customer and service delivery requirements to maximise the business value of the firm's service offerings. We suggest that a role which embraces all three requires firms to deliberately organize and manage ICT deployment in more holistic ways.

The Growth in Services: A $21^{\text {st }}$ Century Phenomenon

Services are fast overtaking products as the basis for the predominant economic model for companies and countries. The success of this model rests in large part on the underlying service logic which substantially reflects relational concerns and has shown to provide sustainable and profitable business propositions to such service providers. The service sector has outpaced product and manufacturing oriented sectors and replaced them as the motor of economic growth. Services account for $75 \%$ of the GDP in the United States and $70 \%$ of the aggregate production and employment in OECD nations (OECD, 2005). In the US 97 per cent of job growth from 1988 to 2000 came from the services sector (Goodman and Steadman, 2000). In the global context internationally the services sector accounts for $\$ 1.6$ trillion of world trade (WTO, 2005). The World Trade Organisation has for the first time ever devised multilateral legally-enforceable rules covering international trade in services. International trade in goods is a relatively simple idea to grasp: a product is transported from one country to another. Trade in services is much more diverse. Telephone companies, banks, airlines and accountancy firms provide their services in quite different ways (WTO, 2005).

Service science is seen as the next frontier discipline after computer and information science (Berry et al., 2006). Vargo and Lusch (2004) suggest that the bases for economic exchange should focus on the provision of services rather than the traditional product focus. They argue that marketing academics have always viewed service as a subset of product marketing and from the perspective of how they differ from products, with limited empirical support for these views. They further suggest that the characteristics and therefore the paradigm from which much of the limited discussion of services flows are flawed. From a global supply chain perspective, Ellram et al. (2004) suggest that service supply chains have been overlooked in favour of product based 
supply chains but that they will grow in importance along with rising spend on the management of service, growing service outsourcing, and the increasing economic importance of service supply chains. As more and more product based companies like IBM, Pitney Bowes and Fujitsu garner so much of their profitability from the service aspects of their business (Neu and Brown, 2000) we need to refocus our efforts on how we study services and how customer avail of services in this global networked economy. As products and services become more aligned and little difference exist between marketing in general and service marketing, service thinking will become the dominant thinking (Stauss, 2005).

In this context we need to ensure that our conceptual foundations are both appropriate and empirically grounded. In short, we need to make sure that we understand contemporary services. The dominant logic of service thinking proposes that "value is created and perceived by the customer. The function of marketing is to develop offers in co-production with customers - whereby customers are presented with attractive value propositions and are supported in the creation of value" (Stauss, 2005:220). The concept of co-production, which is at the heart of the service logic, thus places the relational aspects of the organisation-customer interface at the heart of the value creation model underlying the economic activity of the firm. It replaces a product oriented logic that primarily focuses on the transactional aspects of the interface and moves to a relational prespective (Gummesson, 1998, 2002; Gronross, 2004). "In this service-dominated paradigm relevant concepts from service thinking-such as 'customer integration' 'co-production' and 'relationships' - thus becomes of central importance. The spotlight is on the customers themselves, interaction with these customers and the integration of customers in the production process. In this paradigm any contact with customers is seen as being relational." (Stauss, 2005:220).

Along with such marketing-oriented attempts to understand developments in services, management and organizational implications of service provision too need to receive further attention. Structural and procedural aspects of co-production have profound implications for internal and external organizational arrangements. The next section considers particularly 
the issues arising from the deployment of a central enabler of service provision, namely ICT.

\section{ICT Deployment in Service}

In tandem with the growth in services there has been a phenomenal rise in the adoption of ICT by a wide variety of companies within both product and service domains. To many ICT is viewed as the norm of business practice. Given that services by their nature process large amount of information, they can benefit from the appropriate deployment of a supporting ICT infrastructure. Many services beyond the spheres of traditional service activities such as banking, insurance and travel are also becoming heavily reliant on ICT. Overall, the dominant users of ICT can be found in the service sector (Meyronin, 2004). How can the ICT component of global services be delivered? What are the challenges for this from a management perspective? If global service organisations fully embrace this service logic, what are the implications for the ICT currently in use in their customer offerings, and how can ICT most usefully be deployed in ways that enable efficient as well as relationship-friendly ways?

Much of the growth in internationally traded services has been ICT enabled or induced. Given the increased coordination cost associated with the scale necessary for global service provision, it is not clear if purely transactional advantages arising from global service offerings provide enough value for the such service firms. To fully exploit global service offerings, they need to maximise the value co-constructed with their customers as well as capture a sufficient part of this value. The more value the service encounter creates the more value can be retained by the firm, which suggests that both transactional and relational opportunities inherent in service encounters need to be vigorously pursued.

As Wright (2002) notes within the financial service sector technology induced changes have led to the removal of geographic and cost barrier to global distribution on the supply side and the global convergence in benefits sought by banking consumers on the demand sides and has driven the growth of global banking brands. In their attempts to broaden their geographical reach, global financial services need to stay customer focused. 
Wright (2002:94) argues that it is through ICT that global financial services design and delivery can be sufficiently customized to maximize customer delivered value. Yet the way in which ICT is deployed to manage the customer interface can bring difficulties as well as opportunities.

As an example, the growth in self-service technologies and coproduction of services heralds new and interesting developments at the customer interface (Howard and Worboys, 2003; Meuter et al., 1998, 2000). Academics have observed the growing popularity of self-service technologies and have commented on both the positive and negative consumer perception of same (Howard and Worboys, 2003). Meuter and her colleagues' (2000) empirical study confirms that self-service technology is accepted and growing in popularity particularly when handled as a customer support rather than a cost saving initiative. She did note that only $5 \%$ of customers wanted self-service through all the stages of the decision making process but that they would use self-service as long as a human element was available if needed. It appears that the scope for deploying ICTs that support such self-service based customer interfaces is tremendous. The obvious attraction for service providers is the potential for technology-based efficiency and resulting cost savings. An important challenge for service firms, however, is to not prioritize the technological or economical aspects to the detriment of the value ultimately delivered to their customers.

In this context, a range of challenges arise for global service providers. They need to develop and deploy technological enabled self-service interfaces that are either universally deployable or easily customisable to specific local requirements to exploit the efficiencies inherent in such interface solutions. This is more likely to be possible if the initial capital investment into the development of such interfaces is large, or if specific technological, organisational or managerial knowledge is required for the successful use of such interfaces that in turn is not easy or cheap to develop.

These challenges will make it unlikely that the use of ICT in the global service industry will bring about the demise of the face-to-face encounter. Nevertheless, given the efficiency logic employed by many global service providers it is important to consider if the quest for economic and productivity 
gains through automated service interfaces is detrimental to the customer relationship. A study by Brady et al. (2002) showed that relationship-orientated companies were more proficient users of ICT than transaction-orientated companies. While this seems initially counterintuitive because the former companies deal more intensively with customers, much of this contact is now being mediated through ICT. Is there a loss of value with a rise in ICT, a loss of the interpersonal relationship with the customer? Within business-to-business relationships a recent study showed that the use of internet-based systems decreases the nature and quality of information shared by the participants and reduces the frequency of their interactions. (Schultz and Orlikowski, 2004) Meyronin (2004) suggest that automation contributes to the building of an informational wall. He asks whether the productivity gains from automation compensate for the losses in terms of value and differentiation so often inherent in the deployment of automating technologies. How can ICT based services be distinguished in the eyes of the customer? Does electronic anonymity (Meyronin, 2004) support the service environment?

Service innovation through ICT has often seen the service moved to a transactional rather than a relational focus. For example, a relational dominant marketing practice like book selling can be transformed by placing an ICTbased interface between the customer and the supplier. Now the relational aspects that previously may have been a central part of the customer experience have been incorporated in a transactionally orientated interaction. Service provision becomes skewed towards what the ICT can deliver. As ICT does not enable the relational as much as the transactional, part of the value of the service can be lost as a result. ICT's electronic mediation 'tends to impoverish service relations, insomuch as the technological interface can by no means replace the wealth of human interactions on which the creation of value and the differentiation of services are based'. (Meyronin, 2004:216)

Service in an Automated Environment

The logic of how ICT is assimilated into organisations follows Nolan's (1973) Stage Theory through stages of data processing, personal computing and network, or in Zuboff's (1988) terms automation, information and transformation. Thus the fact that the first wave of ICT assimilations has 
produced efficiency gains rather than relational improvements is accepted but highlights our need to move towards what Nolan called the network era. Aligned to this is the continuing move to ubiquitous computing, Weiser's (1993) $3^{\text {rd }}$ stage of computing. Brady and her colleagues (2002) report that ICT's assimilation into marketing followed the Stages Theory Approach and was predominantly automational in focus, i.e., it is used to automate previously manual tasks and was only slowly resulting in more effectiveness with little evidence of ICT transforming marketing practice. This suggests that ICT in the service domain is replacing the human interface and automating that relationship, thus often turning the customer into a self-service customer and mediating the relationship through ICT. There are obvious effects on the relationship as the buyer/seller roles become blurred and the understanding of each other is ICT mediated and is therefore often more limited. Prahalad and Ramaswamy (2004:7) suggest that in a service era defined by co-creation 'we need to challenge the traditional, distinct roles of both the consumer and the company and examine the impact of a convergence of the roles of production and consumption'. They suggest that the current system of value creation, even when shared with the customer through self-service, is product centric, service centric and company centric rather than customer centric. If we wish to move away from a predominantly technology oriented view then a co-creation view may offer a solution. Prahalad and Ramaswamy (2004) offer dialogue, transparency, access and risk benefits as building blocks of interactions for the co-creation of value. Many of these are driven by ubiquitous connectivity. Much of co-creation has had a company focus, even when the customer is seen to drive innovation or mass customisation. These often suits the company rather than real customer centric focus on co-creation.

Does ICT enable the relational as much as the transactional?

What are the implications for the service encounter when the customer is a self-service customer? Who is managing the interpersonal relationship? Contemporary marketing practice views marketing along a transactional to relational perspective trajectory (see table below). It must be noted that the categories are neither mutually exclusive nor necessarily lie on a single dimension. Coviello and colleagues (2002) have empirically confirmed a 
pluralism of approaches in that marketers have a dominant orientation but practice all other forms too.

\section{Table 1: Marketing Classified by Relational Exchange Dimensions}

\begin{tabular}{|l|l|l|l|l|l|}
\hline & $\begin{array}{l}\text { Transactional } \\
\text { perspective }\end{array}$ & \multicolumn{4}{|c|}{ Relationship Perspective } \\
\hline $\begin{array}{l}\text { Transaction } \\
\text { Marketing }\end{array}$ & $\begin{array}{l}\text { Database } \\
\text { Marketing }\end{array}$ & Emarketing & $\begin{array}{l}\text { Interaction } \\
\text { Marketing }\end{array}$ & Network Marketing \\
\hline
\end{tabular}

Source: Adapted from Coviello et al., 2002

It can be suggested that the more relational a company's marketing practice is, the more they adhere to implicit service logic. Does ICT reduce the relational encounter back to a transactional encounter? In the diagram above emarketing is placed at the relational end of the diargram but this seems contradictory. Within services most text books and authors will discuss the importance of the interpersonal. As Brown (2000: 62) notes the ability to obtain and consume services without interacting with a human provider challenges much of our existing knowledge'. The emphasis on service is also on the life time value or the long term nature of the service. From a transactional perspective the emphasis is on arms length, discrete, once-off, relationshipless interactions. For example within the banking system the introduction of ICT along the value chain has resulted in the automation or transactional focus of much of what was traditional face-to-face or interpersonal banking. Does this add value to the relationship? The reality is that the high net worth customers who the organisation wants a relationship with are now increasingly served through low-value adding ICT service encounters. This negates the banks ability to upsell to them or to develop this relationship further (see figure 1 below). The company has encouraged, and the customer has now accepted, that the service encounter will be transactional, in that it will be arms length, discrete and so on. The relational dimensions have been reduced through decisions on ICT mediated interfaces. Even though this is more efficient for the bank this raises important questions: Does this add value for the customer? And how can the bank differentiate themselves from competitors when their 
products and their service delivery is standardised. Can a transactional approach provide relationship-enhancing, personalised interactions?

Figure 1: Multi-Channel: Value Add of Sale Versus Cost Per Transaction.

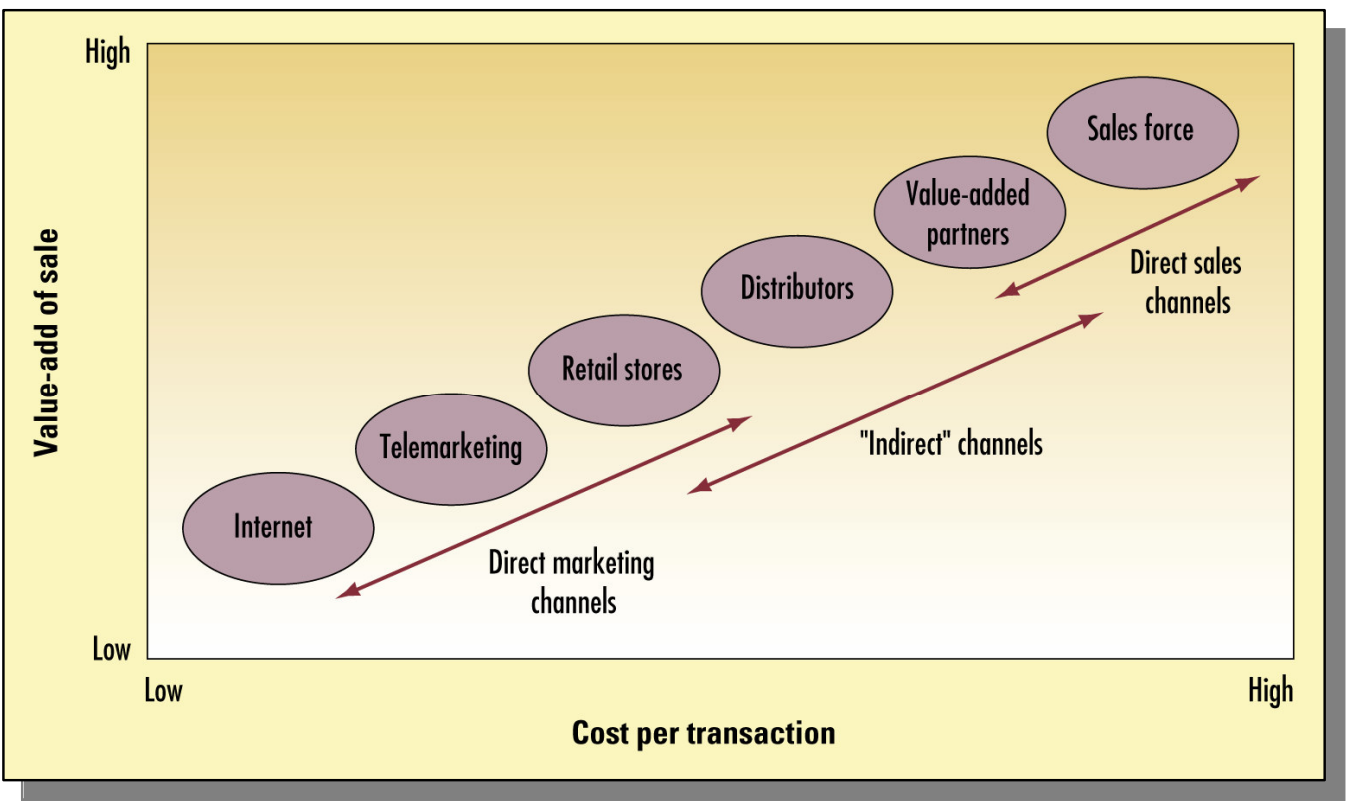

As an aside, the growing popularity of multiple channels for services has been virtually unexplored in the existing literature with an absence of guidelines regarding the design of service specific multiple channels. A recent study by Coelho and Easingwood (2005) suggest that customer heterogeneity, customer volatility and environment conflict influence the choice of multiple rather than single channels. We would suggest that the availability of the technology has driven much of the growth without the corresponding understanding of the implications for the customer relationship as well as for the organization and how it manages it activities. This view is supported by evidence (Coelho and Easingwood, 2005; 208) that multiple channels are often designed in an 'embarrassingly unscientific' manner. Their research lacks a technological orientation which could add further weight to our suggestion.

The Human Dimension of Co-creation

Services ultimately are based on information and/or people. ICT can legitimately cover the information aspect but what is the impact of the people 
aspect? Services traditionally were seen as an opportunity for the joint creation of value. Meyronin (2004:223) notes that 'by replacing the wealth of human interaction with the strict conformity of (ICT) infomediation, service companies are inclined to forget the importance of customer participation in the servuction process, their role as co-producers of a service, co-innovations and the sole evaluators of the quality of the service given. Losing the wealth of human contact and the inherent potential of any encounters in a servuction area in favour of infomediation seems to counter-act an increase in created value'. According to Meyronin (2004) the people elements are: listening to and understanding needs; personalisation of the service; handling crisis situations and socialisation impacts. Meyronin (2004:220) suggests that 'by considerably diminishing the control a service company has over the service relation, infomediation tends to cancel out the positive effects related to 'handling people' to the service's capacity to co-product value and create differentiations with the customer'. De Wulf et al. (2001) note that service firms must arbitrate between the benefits of the automation of the service and the advantages inherent in the human interaction that result from direct contact with the customer.

What are the implications for consumers and service providers? Meyronin (2004) suggests that the consumer loses through increased need for participation, rise in the perception of risk, loss of socialisation, and lack of flexibility in the relationship with the company. Alternatively Bitner et al. (2000) cite the advantages to using ICT self-service technologies as availability in case of emergencies; ease of use; efficiency in terms of time and money; and temporal and geographical availability. Prahalad and Ramaswany (2004) view consumers as co-producers of value and this can be lost in the race for automation for the sake of efficiencies. Services have always viewed the coproducer aspect as important centring it under the inseparability role. Services production and consumption is linked to concepts of interaction and the service encounter: it is the 'moments of truth' when the customer interacts with the company. Co-production moves work from the provider to the consumer as the consumer becomes a partial employee (Gummesson, 1998). ICT can actually obliterate the twin constraints of services, notably perishability and inseparability, and can separate service provider from customer in terms of 
both time and space (Lovelock and Gummesson, 2004:20). 'Technology has transformed many formerly inseparable services into services that can be consumed at any time or place'. (Berry et al., 2006;57).

Implications for the service providers include the potential changes in the design of their jobs. Depending on how ICT is deployed, such mediated customer contact can negatively affect central job characteristics (Hackman \& Oldham, 1980) such as task identity, task significance, skill variety, autonomy, and interpersonal aspects of feedback. The implications of this for co-creation are not yet fully understood.

As Meyronin (2004) asks, what are the losses in terms of creation of value and differentiation and the productivity gains? ICT is used to solve or resolve the problems that occur at the human interface. 'Given that large number of service quality problems which result form incidents that occur between customers and staff, service industries use new technologies more and more in order to reduce or suppress customer contact. Thus telephone conversations have replaced face to face contact and human services are replaced by self- service which often depends on the use of computers and automation.' (Lovelock and Lapert, 1999:34) Bitner et al., (2000) shows that customers can prefer ICT based services because they are disappointed with the human based services.

From an interaction perspective customers have multi-method options of contact and communication and from an information perspective marketing managers have a myriad of ICTs providing them with an avalanche of information to be analysed, manipulated and managed. Our worry is that global service organizations do not have all the skills needed to manage the complex issues arising from their use of currently deployed ICTs, let alone the more innovative and complex ones currently in development. How much ICT, to whom, when and where must be considered from several perspectives before the most appropriate answers can be found.

A particular challenge is the difficulty of predicting the actual impact of ICT on the resulting service proposition for the customer. As the value of offered services is in part created by the customer, the impact of ICT on value co-creation and on the customer's subjective service experience and evaluation is difficult if not impossible to predict. Meyronin (2004:221) provides the 
example of a bank which in its endeavours to become multi-channel [...] has multiplied sources of dissatisfaction, frustration and concern from those who did not purposefully choose ICT based services.' Is increased ICT increasing satisfaction and value? Meuter and colleagues (2000) note that "by increasingly enforcing the use of info-mediation beyond the "technophiles" segment (who have the facilities), service companies are leaving themselves wide open to likely disappointments from those customers who do not have access to and/or who do not like such servuction methods". An alternative view is that there are segments which are ICT literate and demanding, where customers are more technology aware and in that case it could be marketing which is lagging far behind their more technology savvy customers (Spero and Stone, 2004). According to Ranchhod, (2004: 269), many 'current IT systems are not fluid and dynamic enough to cope with customers who are ubiquitous and can contact companies through mail, mobiles and the internet'. This is particular true for the younger generation. Spero and Stone describe this group as living in the digital environment where 'patterns of adaptation mushroom and then wither away quickly, at a pace which is hard to understand, while new technologies are picked up quickly, provided that they observe the basic rules of economy (not too expensive), adaptability (quick, easy and cheap to adapt to user needs), technical pervasiveness (you can use them anywhere) and market pervasiveness (lots of people using them and therefore easy to establish your own network of connection)'. (2004:155)

A key point made by Mitchell (2002) is that no matter how advanced new technologies become, they will never be completely efficient without the input of the consumer. "They depend on customers 'opting in' rather than merely acting as passive targets,...making marketing a joint, cooperative process" (Mitchell 2002:77). In short, in the information age both service providers and customers have a role in shaping and directing their interaction. It remains, however, the service provider's responsibility to make the customers' voice heard in this process.

Towards a Model for Deployment of ICT within the Services Logic

Within this discussion we suggest a customer centric ICT deployment model that is more fully aligned with the service logic. It suggests that 
technologist, marketers and business managers must unite towards a customer centric focus.

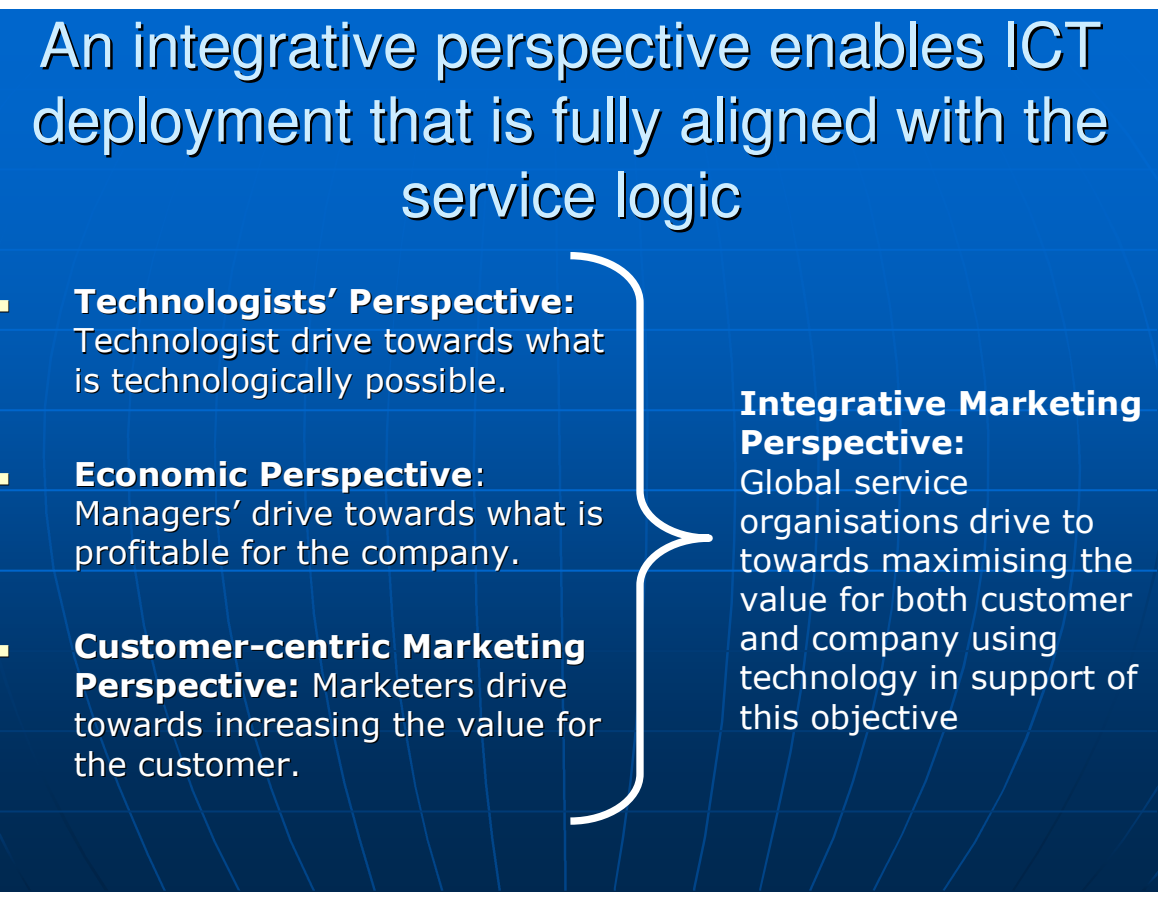

Recognising the challenge of integrating these three orientations is only the first step towards a more holistic deployment of ICT. A second step is to recognise and address the challenge of enabling the organization and coordination of this integration. One suggestion is to deliberately define and fill the arbitration role and coordinate the three different perspectives we have outlined above. There are a number of aspects to this, including the potentially politically difficult task of identifying internal champions, equipping them with the relevant skill-set, and the challenge of enabling them through appropriate organisational arrangements. Also the power base and business orientation is in many global service organisation is finance related and thus often singularly focused on creating and maximising shareholder value rather than jointly maximising longterm customer and organisational value.

In fact, the challenge for the most appropriate deployment of ICT must be integrated into a holistic understanding of at least these three fundamentally different orientations. Specifically, the technologists' drive to apply cutting edge knowledge, to push the boundaries of what is technologically possible, must be 
checked both by the business logic that requires short-term profitability and longer term economic viability and sustainability, and the marketing logic that places customer needs and customer value at the heart of matters. These three different orientations all require attention, but none can on its own deliver the full value required in competitive service markets. Thus, the three sets of objectives require arbitrators that can integrate technological potential with customer and service delivery requirements to maximise the business value of the firm's market offerings.

Diagrammatically, companies have the choice of one or more perspectives from figure 2 below. Our contention is that it should not be any single or any pairing of perspectives, but that all three need to be aligned facing the customer centric model of ICT assimilation. So two out of three as the current focus within companies needs to be replaced by all three with the requiring organisational, managerial and skill set changes. The role of ICT in global service provision also requires the recognition of the requirement to include it in the integration task (re the integration between different perspectives); this needs to include the recognition of the technological perspective (typically exemplified by IS/IT and R\&D), and the value that ICT can add to service delivery and the customer interface management.

Figure 2 Deploying ICT within the Service Logic 


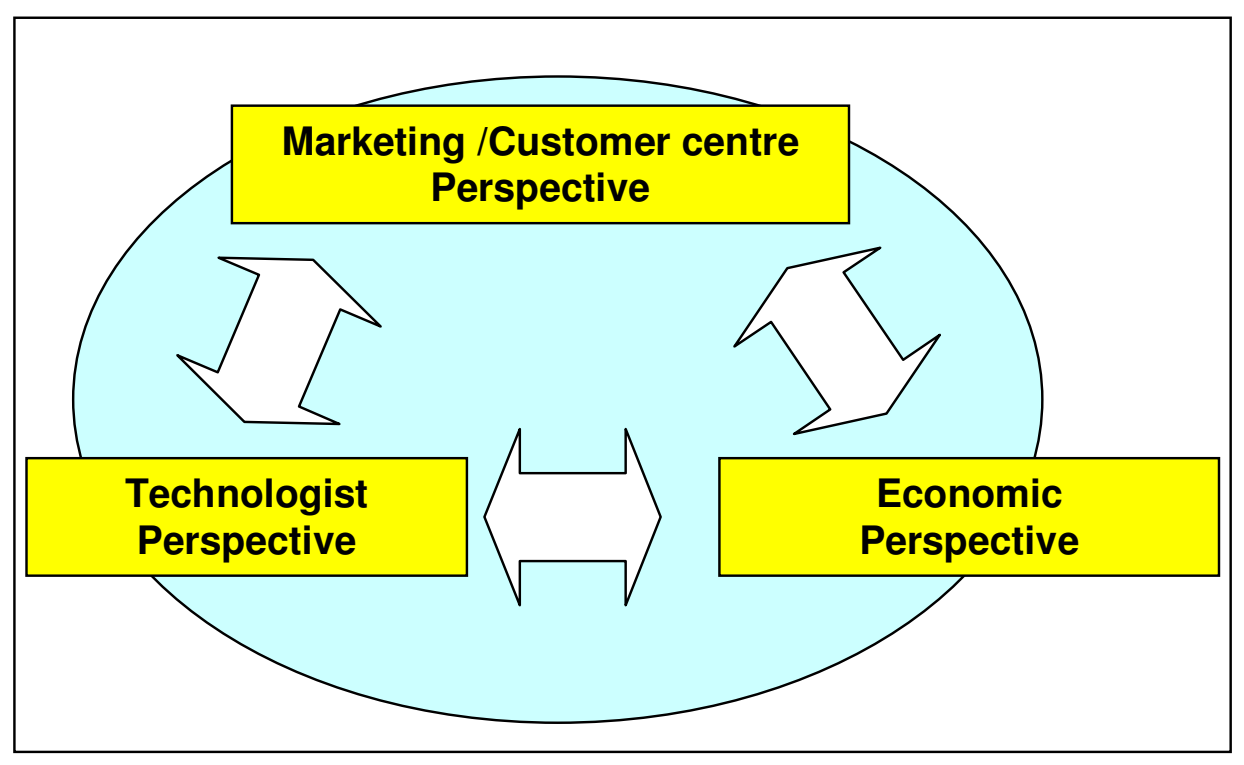

The three sets of objectives require an arbitrators that (a) can understand the individual perspectives and can constructively relate to the respective sets of specialists; (b) can integrate technological potential with customer and service delivery requirements to maximise the business value of the firm's market offerings; and (c) can achieve both strong and sustainable relationships with customers that help differentiation, add value in the service co-creation, and provide a conduit that integrates customers directly into the development of future services and service delivery approaches.

We must reinforce the point that the coordination of the different perspectives identified above is not a fixed sum game. Instead we argue that successful arbitration among these perspectives must help to move towards exploring and increasing the value available for both service provider and customer. In short, it must help pave the way for ICT to help both parties. This can only be achieved when the economic demands of the service provider have as central a role in the deployment of ICT in the service delivery as have the customers' expectation and evaluations. And lastly, both of these perspectives need to be integrated with what the technologists can actually develop and implement.

The tripartite view we propose here places the joint maximisation of the value to the customer and the value to the company at the centre of the 
organisations ICT strategy which must guide the deployment of ICT in the service delivery context. Technology cannot be the tail that wags the dog of cocreation based value maximisation in a service oriented economy.

The arbitrator must

- Understand enough about relevant ICTs to constructively engage with technologists

- Develop the ability to simultaneously maximising the value for customers and capturing sufficient value for the company to make it economically viable and successful

- Learn how to better predict the implications for customer value of ICT integration in products and services (including ICT deployment at the service interface)

- Find organisational solutions that provide the forum for the three different perspectives to be heard and integrated

- Deal with the political and organisational challenges of institutionalising the required internal changes that enable ICT deployment aligned with the Service Logic

\section{Conclusion}

Currently companies' use of ICT as part of their service proposition is too often driven by their technological ability or their economic desire for increased productivity rather than by a more holistic, customer-centric view of how ICT can and should add value to the customer relationship. ICT must be considered in integrative fashion along with economic and customer oriented issues to maximise the value created by service for customer and company. The relational logic should be at the heart of this. Use of ICT must recognise its role for enabling and improving the relational aspects (quality of relationship, duration of relationship, satisfaction with relationship, and so on), not only the efficiency benefits of its transactional role. ICT in service provision is a means, not an end.

Global service companies, driven by the efficiency logic of globalisation, are too often letting the technological tail wag the dog. Rather than focusing on 
what they need to provide customer relational value they are racing towards ICT parity at the risk of damaging their customer relationships and automating some of the most important aspects of the organisations relationships with their customers. Introducing ICT into relationships without a clear understanding and a modelling of the likely effect, driven by 'me too' thinking is a recipe for damaged relationships and arms length dealing with valuable customers who can make the difference between success and failure. The outcome of the changes emerging now as companies rush to introduce ICT across a range of boundary spanning customer interfaces, may result in the long term damage to core customer relationships. Only those companies who can successfully deploy ICT in service innovation and delivery with a customer centric focus will be able to maximise the relational value and will be leading the continued rise of the global service-based economy of the future.

\section{References}

Aharoni, Yair. (1996) "The organization of global service MNEs", International Studies of Management \& Organization. White Plains: Summer, Vol 26, Iss 2; pg 6, 18 pgs

Bartlett, C.A., \& Ghoshal, S. (1987) Managing across borders: New strategic requirements. Sloan Management Review, 7-17.

Berry, L., Venkatesh, S, Parish, J.T., Cadwallader S., and Dotzel, T., (2006) Creating New Markets Through Service Innovation, MIT Sloan Management Review, Winter, Vol 47(2), 56-63

Berthon, P., MacHulbert, J., and Pitt, L., (2005) Consuming Technology: Why Marketers Sometimes get it wrong, California Management Review, 48(1) Fall, 110-128

Bitner, M., J.,Brown, S.W., Meuter, M.L., (2000) Technology infusion in service encounters Academy of Marketing Science Journal, Winter 28 (1) 138150

Boudreau, M.-C., Loch, K.D., Robey, D., \& Straub, D. (1998) "Going Global: Using Information Technology to Advance the Competitiveness of the Virtual Transnational Organization", The Academy of Management Executive, 12, No. 4, pp.120-128 
Brady, M (2006) 'Moving Information: The role of IT'. In Saren, M, Marketing Graffiti, Butterworth Heinemann, Oxford, pp 247-259

Brady, M., Saren, M., Tzokas, N., (2002) "Integrating Information Technology into Marketing Practice - The IT Reality of Contemporary Marketing Practice", Journal of Marketing Management, 18, No. 5-6 July, pp. 555 578

Brown, S., (2000), Part. 4, in Services Marketing Self-Portraits: Introspections, Reflections, and Glimpses from the Experts by R. P. Fisk, S. J. Grove, and J. John, eds. Chicago: American Marketing Association, 53-69.

Brynjolfsson, E., and Hitt, L., (2000) Beyond computation: information technology, organisational transformation and business performance, The Journal of Economic Perspectives Vol. 14, Iss. 4; p. 23-49 http://wwwebusiness.mit.edu/erik/BeyondComputation.html

Coelho, F., and Easingwood, C., (2005) Determinants of Multiple Channel Choice in Financial Services: An Environmental Uncertainty Model, The Journal of Services Marketing, 19(4), 199-211

Coviello, N., Brodie, R., and Munro, H., (1997) Understanding contemporary marketing: development of a classification scheme, Journal of Marketing Management, 13, 501-522

Coviello, N.E., Brodie, R.J., Danaher, P.J., and W. Johnston -46 (2002), "How Firms Relate to Their Markets: An Empirical Examination of Contemporary Marketing Practices," Journal of Marketing, 66(3), 33-46

De Wulf, Kristof., Gaby Odekerken-Schroder, Dawn Lacobucci. (2001) Investments in consumer relationships: A cross-country and crossindustry exploration, Journal of Marketing. Oct Vol. 65(4), 33-51

Ellram, L., Tate, W., \& Billington, C. (2004) Understanding and Managing the Services Supply Chain. Journal of Supply Chain Management. 40(4); pp 17- 33

Goodman, B., and Steadman, R., (2000) Services; Business Demand Rivals Consumer Demand in Driving Job Growth, Monthly Labour Review, 125(4), 3-9

Grönroos, C. (2000) Service Management and Marketing: A Customer Relationship Management Approach, 2nd edn. London: John Wiley. 
Grönroos, C. (2004) The Relationship Marketing Process: Communication, Interaction, Dialogue, Value, The Journal of Business \& Industrial Marketing, Vol 19, No. 2 pg $99-113$.

Gummesson, E., (1998) Implementation requires a relationship marketing paradigm, Academy of Marketing Science Journal, Summer, 242-249

Gummesson, E. (2002) Total Relationship Marketing. Oxford: Butterworth Heinemann.

Hackman, J.R., \& Oldham, G.R. (1980) Work redesign. Reading, MA: Addison-Wesley.

Hirschheim, R and A Schwarz, P Todd (2006) A marketing maturity model for IT: Building a customer-centric IT organization, IBM Systems Journal.. Vol. 45, Iss. 1 ; p. $181-200$

Holland C., and Naude, P. (2004) "The Metamorphosis of Marketing into an Information-handling Problem", Journal of Business and Industrial Marketing 1 19, (3), 167-177

Howard, M., and Worboys, C., (2003) "Self-service - A Contradiction in Terms or Customer-Led Choice, Journal of Consumer Behaviour, Vol 2, No 4, pp. 382-393

Kling, R. (2003). Critical professional education about information and communications technologies and social life, Information Technology \& People, Vol. 16, Iss. 4; p. $394-429$

Levy, M., Powell, P \& Tetton, P. (2001) 'SMEs: aligning IS and the strategic context' Journal of Information Technology, 16, Pg.133-144

Lovelock C., and Gummesson E., (2004). Whither Services Marketing? In Search of a New Paradigm and Fresh Perspectives, Journal of Service Research: Vol. 7, Iss. 1; 20-41

Lovelock, C., and Lapert, D (1999) Marketing Des Services, Editions Publi Union, Paris.

Meuter, M., and Bitner, M. (1998) Self-service technologies; extending service frameworks and identifying research issues. Conference Proceedings of the American Marketing Association, Winter, 12-18

Meuter, M., Ostrom, A., Roundtree, R., and Bitner, M. (2000) Self-service technologies: understanding customer satisfaction with technologybased service encounters, Journal of Marketing 64 (3), 35-46 
Meyronin, B., (2004) ICT: The Creation of value and differentiation in services, Managing Service Quality, 14(2/3), 216-225

Mitchell, S. A. (2002) Do you really want to understand your customer? Journal of Consumer Behaviour, 2 (1), 71-79

Neu, W., and Brown, S (2000) Manufacturers marketing services: Factors underlying the changing business domain, American Marketing Association Conference Proceedings. Chicago:. 11; 189- 191

Nolan, R., (1973) Computer data bases: The future is now, Harvard Business Review, September-October, 98-112

OECD (2005) Annual Report, OECD Publications, Paris, 1-147

Prahalad, C. K. and Ramaswamy. Venkat (2004) Co-creation experiences: The next practice in value creation Journal of Interactive Marketing. Summer. 18(3), 5-14

Ranchhod, A., (2004) "The Changing Nature of Cyber-Marketing Strategies", Business Process Management Journal, 10(3), 262-276

Rust, Roland T and Kannan P. K., (2003). E-service: A new paradigm for business in the electronic environment, Association for Computing Machinery. Communications of the ACM. New York: Jun 2003. 46(6), 37-50

Schultze, U., and Orlikowski, W., (2004) "A Practice Perspective on Technology-Mediated Network Relations: The Use of Internet-Based Self-Serve Technologies. Information Systems Research; Vol. 15, 1 pp. 87-106

Shore, Barry. (2006) "Enterprise integration across the globally disbursed service organization", Association for Computing Machinery. Communications of the ACM. New York: Jun, Vol. 49, Iss. 6; p. 102

Spero, I., and Stone, M., (2004) Agents of change: how young consumers are changing the world of marketing, Qualitative Market Research. 7(2); 153168

Stauss, B (2005) A Pyrrhic Victory: The Implications of an Unlimited Broadening of the Concept of Services, Managing Service Quality, 15(3), 219-229 
Weiser, Mark. (1993) "Some computer science issues in ubiquitous computing", Association for Computing Machinery. Communications of the ACM, New York: Jul, Vol 36, Iss 7, pp 74-85.

Wright, A., (2002) Technology as an enabler of the Global Branding of Retail Financial Service, Journal of International Marketing, 10(2), 83-98

Vargo, Stephen L., and Lusch, Robert F., (2004) The Four Service Marketing Myths: Remnants of a Goods-Based, Manufacturing Model, Journal of Service Research, 6(4), 324-335

Zuboff, S., (1988) In the Age of the Smart Machine, Heinemann Professional Publishing, Oxford

WTO

Http://www.wto.org/english/thewto e/minist e/min99 e/english/about e/09serv e.htm 


\section{Appendix 1}

\section{Appendix 1: MarklTing: A Framework for ICTs:}

\section{The information and interactions dimensions}

\begin{tabular}{|c|c|}
\hline $\begin{array}{l}\text { Information } \\
\text { (Research, Analysis and Planning) }\end{array}$ & $\begin{array}{l}\text { Interactions } \\
\text { (Communications, Connections and Collaborations) }\end{array}$ \\
\hline Analysis and Planning & Communications \\
\hline Marketing planning systems & Internet \\
\hline Performance tracking software & - Website design software: Photoshop \\
\hline Executive support systems & -Website security \\
\hline Decision support systems & -Interactive website applications \\
\hline ERP (Enterprise Resource Planning) & -Ecommerce applications \\
\hline Knowledge Management Systems & Intranets \\
\hline Pricing software & Extranets \\
\hline Project Management Software & Electronic data interchange (EDI) \\
\hline Promotion Tracking software & Email \\
\hline Media Spend analysis packages & Video conferencing \\
\hline Logistics Systems & Call centre \\
\hline Geographical Information Systems & CATI - computer-aided telephone interviewing \\
\hline Customer Profitability analysis & Automatic Call Distribution \\
\hline PRISM Clusters - databases & Computer telephony integration \\
\hline Forecasting Software & Mobile communication devices \\
\hline Marketing modelling & Instant Messaging \\
\hline Information systems (SAP, PeopleSoft and i2) & Tracking Devices - Blue Tooth \\
\hline Databases & SMS - simple messaging service \\
\hline Centralised customer database & Facsimile communications \\
\hline -Integrated with sales & Electronic markets \\
\hline -Integrated with call centre & Help lines \\
\hline -Integrated with internet & Voice Mail \\
\hline -integrated with point of sale & Spam blocking systems \\
\hline Data consolidation and display & Voice activated/recognition software \\
\hline Data mining & Computer links with suppliers \\
\hline Data warehousing & Computer links with customers \\
\hline Data Profiling & Web Casting \\
\hline Data Visualisation and Analysis Packages & Web meetings: WebEx \\
\hline GQL - Graphical Query Language & Digital Imaging Software \\
\hline SQL & Self-Service Technologies \\
\hline Research & Integrated TV and Internet - TIVO \\
\hline Internet & Internet Technology \\
\hline Marketing Information System & ATM, \\
\hline Data Analysis Packages & Automated Vending machines \\
\hline Geographic Information Systems & Hand held Scanners \\
\hline Demographic online systems & Biometrics \\
\hline Internet Survey - design and application & Mobile phones \\
\hline Online mailing lists & Blue Tooth Technologies \\
\hline Nielsen Information database & Monitoring devices \\
\hline Web Analytical Technologies & Customisation software \\
\hline Website Performance and Activity tracking & Personalisation software \\
\hline Monitoring and Tracking Software & Sales Related \\
\hline
\end{tabular}




\begin{tabular}{|c|c|}
\hline Searchable Databases & Customer relationship management \\
\hline Customer Relationship Management & Sales force automation packages \\
\hline CRM Software & Mobile phones \\
\hline Customised front office/back office systems & Laptops \\
\hline Marketing Evaluation Software & Telemarketing \\
\hline Contact Management Software & Customised sales force systems \\
\hline Personalisation Technologies & Point of sale information systems \\
\hline Customisation Technologies & Customised Customer Applications \\
\hline Retailing System & Access databases \\
\hline Electronic Point of Sale & Sales Reporting Software \\
\hline Planogram, Spaceman Category Management & Supply Chain Management \\
\hline Personalisation/customisations & Supply Chain Management Software (SCM) \\
\hline Bar codes - scanning & Automated Production \\
\hline New Product Development & Internet marketplace Emarketplace/Ehub \\
\hline Product Development and Design software & Inventory management software \\
\hline Simulation technologies & Material planning and supply software \\
\hline Idea generation tool: Idea Garden - & Electronic Data Interchange \\
\hline Imaginatik's Idea Central & QR/ECR (Efficient Customer Response software \\
\hline Statistical tools & Eprocurement systems \\
\hline CAD Computer Aided Design & Online purchasing transactions \\
\hline Others & RFID (Radio Frequency Identification Devices) \\
\hline Training and Educational Software & $\begin{array}{l}\text { Interactive Products } \\
\text { Biometric } \\
\text { Voice Recognition Software } \\
\text { Blue tooth technologies }\end{array}$ \\
\hline \multicolumn{2}{|c|}{ General Underlying and Platform Technologies } \\
\hline \multicolumn{2}{|c|}{$\begin{array}{l}\text { Hardware: Personal Computers, Networked Computers, Main Frame, Laptops, Personal Palm Computers, } C D \\
\text { ROM/DVD, Mobile Phones. Digital Assistants. } \\
\text { Office Packages: Word, PowerPoint, Excel } \\
\text { Internal Communications Groupware Systems Lotus Notes, Wide/local area networks - Wan/LAN }\end{array}$} \\
\hline
\end{tabular}

